\title{
Peningkatan Determinan Sosial dalam Menurunkan Kejadian Tuberkulosis Paru
}

\section{Social Determinants Improvement in Reducing Tuberculosis Incidence}

\author{
Dyah Wulan Sumekar Rengganis Wardani
}

Bagian Ilmu Kesehatan Masyarakat Fakultas Kedokteran Universitas Lampung

\begin{abstract}
Abstrak
Upaya pengendalian tuberkulosis paru oleh World Health Organization telah meningkatkan angka kesembuhan dan menyelamatkan banyak jiwa, tetapi kurang berhasil dalam menurunkan insiden tuberkulosis. Oleh karena itu, pengendalian tuberkulosis akan lebih menekankan pada kebijakan determinan sosial karena determinan sosial secara langsung maupun melalui faktor risiko tuberkulosis berpengaruh terhadap tuberkulosis. Di Bandar Lampung, angka notifikasi tuberkulosis dari tahun 2009 - 2010 mengalami peningkatan walaupun angka kesembuhan sudah lebih dari $85 \%$. Bandar Lampung juga merupakan bagian dari salah satu provinsi termiskin di Indonesia. Penelitian ini bertujuan untuk mempelajari pengaruh determinan sosial (yang diukur melalui indikator pendidikan, pendapatan dan kelas sosial) terhadap kejadian tuberkulosis. Penelitian dilakukan pada bulan Juli - Oktober 2012 di seluruh pelayanan kesehatan di Bandar Lampung yang telah melaksanakan strategi Directly Observed Treatment Shortcourse. Responden penelitian ini adalah 238 penderita tuberkulosis basil tahan asam positif dan 238 suspek yang tidak menderita tuberkulosis. Hasil penelitian menunjukkan bahwa determinan sosial yang rendah akan meningkatkan risiko untuk terkena tuberkulosis. Oleh karena itu, pengendalian tuberkulosis perlu disertai dengan peningkatan determinan sosial untuk menurunkan kejadian tuberkulosis.

Kata kunci: Determinan sosial, insiden, tuberkulosis
\end{abstract}

\footnotetext{
Abstract

Tuberculosis control program conducted by World Health Organization, has increased tuberculosis cure rate and saved million people, but has less success in reducing tuberculosis incidence. Therefore, tuberculosis control program needs to put more emphasis on social determinants. It is obvious, since social determinants, directly or through its tuberculosis-risk factors, affect tuberculosis. In Bandar Lampung, notification rate during the period of 2009 - 2010 has increased although the cure rate of the period was more than $85 \%$. Moreover, Bandar Lampung is located in Lampung, one of the
}

poorest provinces in Indonesia. This research aimed to study the influence of social determinants (measured by indicators of education, income and social class) affecting tuberculosis incidence. The study was conducted during July - October 2012 at all health services, which has been implementing Directly Observed Treatment Shortcourse strategy, across the Bandar Lampung City. Respondents of this research consisted of 238 smear-positive tuberculosis patients and 238 suspects without tuberculosis. The result showed that the lower social determinants, the higher risk of suffering from tuberculosis. It can be learned that tuberculosis control should be accompanied by an effort of improving social determinants in order to reduce the incidence of tuberculosis.

Keywords: Social determinants, incidence, tuberculosis

\section{Pendahuluan}

Sejak tahun 1947 World Health Organization (WHO) telah melakukan berbagai upaya pengendalian tuberkulosis; mulai dari pemanfaatan obat-obatan, pengembangan program pelayanan dan manajemen pengendalian, pengembangan strategi Directly Observed Treatment Shortcourse (DOTS) hingga pemembentukan Stop TB Partnership pada tahun 2000. Salah satu target yang harus dicapai oleh Stop TB Partnership berkaitan dengan Millenium Development Goals (MDGs) adalah menurunkan insiden kasus hingga $<1 / 1$ juta populasi per tahun pada tahun 2050.1,2 Berbagai upaya pengendalian tersebut dapat meningkatkan angka kesembuhan dan menurunkan angka kematian akibat tuberkulosis. Pada tahun 1995, angka kesembuhan

Korespondensi: Dyah Wulan Sumekar Rengganis Wardani, Bagian Ilmu Kesehatan Masyarakat, FK Universitas Lampung, Jl. S. Brojonegoro No. 1 Bandar Lampung, Hp.08122516128, e-mail:dwwardani@yahoo.com 
berkisar $50 \%$ naik hingga mencapai $88 \%$ pada tahun 2008 atau berkisar 36 juta jiwa. Selain itu, lebih dari enam juta jiwa penderita tuberkulosis dapat diselamatkan pada tahun 1995 dan $2008 .{ }^{3}$ Akan tetapi, upaya tersebut kurang berhasil dalam menurunkan insiden kasus tuberkulosis. Insiden kasus antara tahun 2004 2008 hanya mengalami penurunan sekitar 0,7\% tiap tahunnya. ${ }^{3}$ Penurunan tersebut hanya terjadi di beberapa negara di Amerika dan Eropa, tetapi tidak di 13 negara dengan insiden tuberkulosis tinggi seperti SubSahara Afrika dan Asia Tenggara, termasuk Indonesia. ${ }^{4}$ Insiden kasus di negara-negara tersebut pada tahun 2012 juga tidak mengalami penurunan dibanding insiden kasus pada tahun-tahun sebelumnya. ${ }^{5}$

Oleh karena itu, Direktur Departemen Stop TB WHO menyatakan bahwa untuk menurunkan insiden tuberkulosis, pengendalian tuberkulosis akan "bergerak keluar dari kotak tuberkulosis" dengan menekankan pada isu determinan sosial. Hal tersebut didasari pada pentingnya kebijakan dan intervensi determinan sosial pengendalian tuberkulosis. ${ }^{6}$ Lebih jauh, determinan sosial secara langsung atau melalui faktor risiko tuberkulosis berhubungan dengan kejadian tuberkulosis. Dengan adanya perbedaan determinan sosial, sekelompok orang akan mempunyai faktor risiko tuberkulosis yang lebih baik atau lebih buruk dibanding kelompok lain, yang membuatnya menjadi lebih rentan atau lebih kebal terhadap tuberkulosis. ${ }^{7,8}$ Faktor risiko tuberkulosis yang dimaksud mencakup keamanan pangan, kondisi rumah, akses ke pelayanan kesehatan serta perilaku mengenai HIV, merokok, malnutrisi, diabetes melitus (DM), dan alkohol. ${ }^{7}$ Sedangkan determinan sosial mencakup pendidikan, pekerjaan, pendapatan, kelas sosial, ras atau etnik dan gender. 8,9

Bandar Lampung merupakan salah satu kota di Provinsi Lampung dengan insiden kasus tuberkulosis terbesar di Provinsi Lampung. ${ }^{10}$ Berdasarkan data Dinas Kesehatan Kota (DKK) Bandar Lampung tahun 2009 dan 2010, walaupun angka kesembuhan tuberkulosis pada tahun 2009 dan 2010 berkisar 80 - 85\%, insiden kasus dari tahun ke tahun mengalami peningkatan. Pada tahun 2009, insiden kasus sebesar 112 per 100.000 penduduk, meningkat menjadi 114 per 100.000 penduduk. Selain itu, pada tahun 2010 Provinsi Lampung juga merupakan salah satu provinsi termiskin di Indonesia, termasuk di dalamnya adalah Bandar Lampung. ${ }^{11}$ Penelitian ini bertujuan untuk mempelajari apakah peningkatan determinan sosial akan menurunkan insiden tuberkulosis.

\section{Metode}

Penelitian ini dilakukan di seluruh puskesmas dan rumah sakit di Bandar Lampung yang telah melaksanakan DOTS, yang berjumlah 27 puskesmas dan 1 rumah sakit. Penelitian dilakukan pada bulan Juli 2012 -
Oktober 2012.

Populasi penelitian ini terdiri dari populasi kasus dan populasi kontrol. Populasi kasus terdiri dari 628 penderita tuberkulosis BTA positif yang tercatat di tempat studi pada periode Januari - Juli 2012. Populasi kontrol adalah suspek tuberkulosis yang tidak menderita tuberkulosis, yang didukung dengan hasil laboratorium yang negatif atau pemeriksaan rontgen, yang tercatat di tempat studi pada periode Januari - Juli 2012. Jumlah sampel pada kelompok kasus dan kelompok kontrol, berdasarkan metode penghitungan sampel untuk kelompok kasus dan kelompok kontrol, masing-masing adalah 238. ${ }^{12}$ Pada penelitian ini, jumlah sampel 238 digunakan untuk mengklarifikasi pengaruh yang signifikan secara statistik pada power $80 \%$ dan tingkat kemaknaan $95 \%$.

Pada penelitian ini, variabel penelitian terdiri dari variabel bebas dan variabel terikat. Variabel terikat pada penelitian ini adalah sakit tuberkulosis (ya dan tidak), sedangkan variabel bebas terdiri dari determinan sosial, yang diukur melalui indikator pendidikan (jumlah tahun pendidikan yang diselesaikan kepala rumah tangga $<9$ tahun dan $>9$ tahun), pekerjaan (pekerjaan kepala rumah tangga tidak bekerja dan bekerja), pendapatan (pendapatan per kapita keluarga dengan perbandingan merujuk pada pendapatan per kapita Kota Bandar Lampung $<$ Rp 16.391.999 dan >16.391.999) dan kelas sosial (kepemilikan sumber daya produktif keluarga yang dapat menambah penghasilan tidak mempunyai dan mempunyai sumber daya produktif). $8,9,13,14$

Pengumpulan data pada penelitian ini dilakukan dengan wawancara menggunakan alat bantu kuesioner. Data yang terkumpul kemudian dianalisis dengan menggunakan analisis bivariat dan multivariat regresi logistik untuk mengetahui besar pengaruh variabel bebas yang diteliti terhadap insiden tuberkulosis.

Ethical clearance pada penelitian ini diperoleh dari Komiter Etik Penelitian Kedokteran dan Kesehatan, Fakultas Kedokteran, Universitas Gadjah Mada. Selain itu, seluruh responden yang terlibat dalam penelitian juga berpartisipasi secara sukarela dan mendapatkan informasi yang cukup sebelum dilakukannya wawancara.

\section{Hasil}

Pada penelitian ini, kelompok kasus lebih banyak yang berpendidikan tinggi, bekerja, mempunyai pendapatan rendah dan tidak mempunyai sumber daya produktif. Sedangkan kelompok kontrol lebih banyak yang berpendidikan tinggi, bekerja, mempunyai pendapatan tinggi dan mempunyai sumber daya produktif.

Hasil analisis bivariat dengan menggunakan tabulasi silang dan uji kai kuadrat ditampilkan pada Tabel 1 . Tabel tersebut menunjukkan bahwa indikator pendidikan, pendapatan dan kelas sosial berpengaruh terhadap kejadian tuberkulosis, sedangkan indikator peker- 
Tabel 1. Karakteristik Indikator Determinan Sosial dan Kejadian Tuberkulosis

\begin{tabular}{|c|c|c|c|c|c|c|}
\hline \multirow{2}{*}{$\begin{array}{l}\text { Indikator } \\
\text { Determinan } \\
\text { Sosial }\end{array}$} & \multirow{2}{*}{ Kategori } & \multicolumn{2}{|c|}{ Kelompok } & \multirow{2}{*}{ OR } & \multirow{2}{*}{$95 \%$ CI } & \multirow{2}{*}{ Nilai $p$} \\
\hline & & Kasus & Kontrol & & & \\
\hline \multirow[t]{2}{*}{ Pendidikan } & Rendah & $84(77,1 \%)$ & $25(22,9 \%)$ & \multirow[t]{2}{*}{4,647} & \multirow[t]{2}{*}{$2,840-7,603$} & \multirow[t]{2}{*}{0,001} \\
\hline & Tinggi & $154(40,0 \%)$ & $213(50,0 \%)$ & & & \\
\hline \multirow[t]{2}{*}{ Pekerjaan } & Tidak bekerja & $90(49,2 \%)$ & $93(50,8 \%)$ & \multirow[t]{2}{*}{0,948} & \multirow[t]{2}{*}{$0,655-1,372$} & \multirow[t]{2}{*}{0,777} \\
\hline & Bekerja & $148(50,2 \%)$ & $145(49,8 \%)$ & & & \\
\hline \multirow[t]{2}{*}{ Pendapatan } & Rendah & $167(77,0 \%)$ & $50(23,0 \%)$ & \multirow[t]{2}{*}{8,844} & \multirow[t]{2}{*}{$5,825-13,428$} & \multirow[t]{2}{*}{0,001} \\
\hline & Tinggi & $71(27,4 \%)$ & $188(72,6 \%)$ & & & \\
\hline \multirow[t]{2}{*}{ Kelas sosial } & Tidak punya sumber daya produktif & $183(70,9 \%)$ & $75(29,1 \%)$ & \multirow[t]{2}{*}{7,231} & \multirow[t]{2}{*}{$4,814-10,863$} & \multirow[t]{2}{*}{0,001} \\
\hline & Punya sumber daya produktif & $55(25,2 \%)$ & $163(74,8 \%)$ & & & \\
\hline
\end{tabular}

jaan tidak berpengaruh terhadap kejadian tuberkulosis. Tabel 1 juga menunjukkan bahwa nilai odds ratio (OR) pada indikator pendidikan, pendapatan dan kelas sosial $>1$, yang berarti indikator pendidikan, pendapatan dan kelas sosial merupakan faktor risiko terhadap kejadian tuberkulosis. Hal tersebut didukung hasil tabulasi silang yang menunjukkan bahwa pada kelompok kasus, responden terbanyak mempunyai pendidikan, pendapatan dan kelas sosial yang rendah. Sedangkan pada kelompok kontrol, responden terbanyak mempunyai pendidikan, pendapatan dan kelas sosial yang tinggi.

Hasil analisis multivariat regresi logistik, yang juga merupakan hasil analisis multivariat regresi logistik akhir, ditunjukkan oleh Tabel 2. Pada analisis tersebut, hanya indikator yang berpengaruh terhadap kejadian tuberkulosis yang diikutsertakan, yaitu indikator pendidikan, pendapatan dan kelas sosial. Hasil analisis menunjukkan bahwa secara bersama-sama indikator pendidikan ( $\mathrm{OR}=2,614)$, pendapatan $(\mathrm{OR}=4,048)$ dan kelas sosial $(\mathrm{OR}=2,366)$ berpengaruh terhadap kejadian tuberkulosis. Hasil analisis juga menunjukkan bahwa indikator pendidikan, pendapatan dan kelas sosial dapat menjelaskan 34,8\% variasi kejadian tuberkulosis, sedangkan $65,2 \%$ variasi kejadian tuberkulosis dijelaskan oleh variabel lain yang tidak diteliti pada penelitian ini.

Hasil uji interaksi antara variabel pendidikan dan pendapatan menunjukkan tidak ada interaksi diantara kedua variabel tersebut ( $\mathrm{p}$ variabel moderat=0,241). Hasil uji interaksi juga menunjukkan tidak ada interaksi antara variabel pendapatan dan kelas sosial ( $\mathrm{p}$ variabel moderat $=0,164$ ) serta antara variabel pendidikan dan kelas sosial ( $p$ variabel moderat $=0,922)$. Oleh karena tidak terdapat interaksi antar variabel, model yang dihasilkan pada Tabel 2 merupakan model akhir analisis multivariat pada penelitian ini.

\section{Pembahasan}

Pada hasil analisis bivariat, indikator pendidikan, pendapatan dan kelas sosial berhubungan dengan keja-
Tabel 2. Model Regresi Logistik Indikator Determinan Sosial dan Kejadian Tuberkulosis

\begin{tabular}{lcccc}
\hline Variabel & B & Nilai $\mathbf{p}$ & Exp (B) & 95\% CI \\
\hline Pendidikan & 0,961 & 0,001 & 2,614 & $1,510-4,524$ \\
Pendapatan & 1,398 & 0,001 & 4,048 & $2,279-7,191$ \\
Kelas sosial & 0,861 & 0,003 & 2,366 & $1,337-4,186$ \\
\hline
\end{tabular}

dian tuberkulosis. Hasil penelitian ini sesuai dengan penelitian yang dilakukan di Afrika Selatan serta di Reciffe, Brazil, yang menunjukkan bahwa pendidikan kurang dari 9 tahun serta tidak bisa membaca dan menulis merupakan faktor risiko sakit tuberkulosis. ${ }^{15,16}$ Hasil penelitian ini juga sesuai dengan penelitian yang mempelajari pendapatan dan sakit tuberkulosis di daerah perdesaan China serta penelitian di Aligarh, India, yang menyatakan ada hubungan antara pendapatan terhadap sakit tuberkulosis. ${ }^{17,18}$ Lebih lanjut, hasil ini juga sesuai dengan penelitian yang mempelajari kelas sosial dan sakit tuberkulosis di daerah pedesaan China dan Reciffe, Brazil, yang menyatakan ada hubungan antara kelas sosial dan sakit tuberkulosis. ${ }^{16,17}$ Akan tetapi, hasil penelitian ini tidak sesuai dengan hasil penelitian di Afrika Selatan, di Reciffe, Brazil, dan di Addis Ababa, Afrika Selatan, yang menunjukkan bahwa bekerja dalam kurun waktu tertentu sebelumnya menurunkan risiko tuberkulosis dan tidak bekerja akan meningkatkan risiko tuberkulosis. ${ }^{15,16}$ Ketidaksesuaian tersebut disebabkan karena pada penelitian ini, persentase tidak bekerja pada kelompok kasus dan kelompok kontrol yang tidak terlalu banyak berbeda. Hal tersebut disebabkan oleh adanya responden wanita dan responden berusia lanjut yang tidak bekerja, yang tersebar hampir merata di kelompok kasus dan kelompok kontrol.

Hasil analisis multivariat pada penelitian ini menunjukkan bahwa pendidikan, pendapatan, dan kelas sosial secara bersama-sama berpengaruh terhadap kejadian tuberkulosis. Hasil ini sesuai dengan beberapa penelitian yang menyatakan bahwa pendidikan, pekerjaan, penda- 
patan dan kelas sosial berkaitan dengan kesehatan yang lebih baik. ${ }^{8,9,19}$ Hasil penelitian ini juga sesuai dengan penelitian lain yang menyatakan bahwa determinan sosial, yang diukur melalui pendidikan, pekerjaan, pendapatan dan kelas sosial, berhubungan langsung terhadap kejadian tuberkulosis. ${ }^{3,7}$

Berdasarkan uraian di atas, kejadian tuberkulosis di Bandar Lampung sangat berkaitan dengan determinan sosial yang rendah. Oleh karena itu, untuk menurunkan insiden kasus tuberkulosis di Bandar Lampung diperlukan suatu upaya yang memperhatikan spesifikasi tersebut. Hal tersebut sesuai dengan strategi nasional pengendalian tuberkulosis di Indonesia 2010 - 2014, yang menyatakan bahwa dalam menghadapi kebutuhan masyarakat miskin-rentan, implikasi yang lebih luas dalam pengendalian tuberkulosis adalah dengan mengembangkan model yang spesifik dalam implementasi strategi DOTS di propinsi dan kabupaten/ kota. ${ }^{20}$

Berdasarkan hasil penelitian ini, pengembangan model dalam implementasi strategi DOTS adalah dengan dengan peningkatan determinan sosial, yaitu pendidikan, pendapatan dan kelas sosial. Peningkatan indikator-indikator determinan sosial tersebut dapat dimulai dari peningkatan pendidikan. Hal tersebut sesuai dengan penelitian lain yang menyatakan bahwa pendidikan berkaitan erat dengan pekerjaan, pendapatan dan kesejahteraan. Pencapaian pendidikan yang lebih tinggi akan berkaitan dengan pekerjaan yang lebih baik dan kondisi kerja yang lebih sehat. Pendidikan yang tinggi juga akan meningkatkan kesempatan untuk penghasilan, pendapatan yang lebih besar dan kepemilikan sumber daya produktif yang lebih banyak. ${ }^{19}$

Upaya peningkatan pendidikan yang dapat dilakukan adalah melalui pendidikan nonformal karena penderita tuberkulosis pada penelitian ini sudah melewati usia wajib belajar. Pendidikan nonformal adalah kegiatan di luar sistem sekolah yang dilakukan secara mandiri atau merupakan bagian penting dari kegiatan yang lebih besar, yang dilakukan untuk melayani peserta didik tertentu dalam mencapai tujuan pembelajarannya. Tujuan pendidikan nonformal diantaranya adalah untuk mengembangkan jiwa wirausaha yang mandiri, meningkatkan kompetensi untuk bekerja dalam bidang tertentu, dan/atau melanjutkan pendidikan ke jenjang yang lebih tinggi. ${ }^{21}$ Pendidikan nonformal yang dapat dilakukan adalah dengan memberikan pendidikan dan latihan kerja yang langsung dapat diaplikasikan yang didampingi dengan pemberian pinjaman bergulir untuk membuka usaha sesuai dengan kemampuan yang telah diperoleh. Upaya peningkatan determinan sosial dalam penanggulangan tuberkulosis yang pernah dilakukan adalah proyek "Fighting Poverty to Control TB Project", di Lima, Peru. Proyek tersebut mencakup peningkatan akses ke pelatihan kerja, pemberian pinjaman modal dan dukungan untuk usaha kecil. Evaluasi proyek tersebut menunjukkan bahwa proyek tersebut dapat mengurangi kemiskinan. Bersama dengan strategi DOTS, proyek tersebut sangat bermanfaat dalam penanggulangan tuberkulosis. ${ }^{22}$

Upaya peningkatan determinan sosial dalam penanggulangan tuberkulosis memerlukan dukungan upaya kesehatan lain di luar penanggulangan tuberkulosis, sektor lain di luar kesehatan serta partisipasi masyarakat. Upaya peningkatan pendidikan melalui pendidikan dan latihan kerja dapat dilakukan dengan dukungan Dinas Pendidikan. Selain itu, upaya peningkatan determinan sosial dalam penanggulangan tuberkulosis juga perlu mendapat dukungan dari pemerintah. Dukungan tersebut dapat dilakukan dengan lebih mengimplementasikan kebijakan penanggulangan tuberkulosis, khususnya yang berkaitan dengan salah satu tujuan The Stop Tuberculosis Strategy dalam mencapai MDGs, yaitu melindungi populasi yang rentan terhadap tuberkulosis, dengan komponen memenuhi kebutuhan penduduk miskin dan rentan. ${ }^{23}$ Dukungan juga dapat berupa pembangunan ekonomi dan kebijakan sosial yang memihak masyarakat miskin dan memperhatikan ketidaksamaan determinan sosial, penguatan sistem kesehatan dan manajemen pengendalian tuberkulosis serta komitmen pemerintah pusat dan daerah. ${ }^{20}$

\section{Kesimpulan}

Determinan sosial yang diukur melalui pendidikan, pendapatan dan kelas sosial, berhubungan dengan kejadian tuberkulosis. Indikator pendidikan, pendapatan dan kelas sosial yang rendah, secara bersama-sama meningkatkan risiko kejadian tuberkulosis paru. Oleh karena itu, peningkatan determinan sosial melalui peningkatan pendidikan, pendapatan dan kelas sosial diharapkan akan dapat menurunkan kejadian tuberkulosis paru.

\section{Saran}

Penanggulangan tuberkulosis perlu disertai dengan upaya peningkatan determinan sosial, yaitu melalui peningkatan pendidikan yang berupa pendidikan nonformal. Peningkatan pendidikan tersebut diharapkan dapat meningkatkan indikator pendapatan dan kelas sosial. Upaya tersebut memerlukan dukungan tidak hanya dari instansi kesehatan tetapi juga dari instansi di luar kesehatan dan pemerintah. Penanggulangan tuberkulosis yang disertai dengan peningkatan determinan sosial diharapkan dapat menurunkan kejadian tuberkulosis, khususnya di Bandar Lampung.

\section{Daftar Pustaka}

1. Raviglione MC, Pio A. Evolution of WHO policies for tuberculosis control, 1948 - 2001. The Lancet. 2002; 359: 775-80. 
2. Stop TB Partnership WHO. The stop TB strategy. Building on and enhancing DOTS to meet the TB-related millennium development goals. Geneva: WHO; 2006.

3. Lönnroth K, Castro KG, Chakaya JM, Chauhan LS, Floyd K, Glaziou P, et al. Tuberculosis control and elimination 2010 - 50: cure, care, and social development. The Lancet. 2010; 375 (9728): 1814-29.

4. Dye C, Lönnroth K, Jaramillo E, Williams B, Raviglione M. Trends in tuberculosis incidence and their determinants in 134 countries. Bulletin World Health Organization. 2009; 87: 683-91.

5. WHO. Global tuberculosis report 2013. Geneva: WHO; 2013.

6. Raviglione. Tuberculosis prevention, care and control, 2010-2015: framing global and WHO strategic priorities. Geneva: WHO; 2009.

7. Lönnroth K. Risk factors and social determinants of TB [online]. 2011 [cited 2012 Jul 12]. Available from: http://www.bc.lung.ca/association_and_services/documents/KnutUnionNARTBriskfactorsanddetermi nantsFeb2011.pdf

8. CSDH. A conceptual framework for action on the social determinants of health. Geneva: WHO; 2007.

9. Solar O, Irwin A. A conceptual framework for action on the social determinants of health. Social determinants of health discussion paper 2 (policy and practice). Geneva: WHO; 2010.

10. Dinas Kesehatan Provinsi Lampung. Profil kesehatan Provinsi Lampung 2008. Bandar Lampung: Dinas Kesehatan Provinsi Lampung; 2008.

11. Badan Pusat Statistik. Perkembangan beberapa indikator utama Indonesia. Jakarta: Badan Pusat Statistik; 2011.

12. Lemeshow S, David Jr. Besar sampel dalam penelitian kesehatan (terjemahan). Yogyakarta: Gadjah Mada University Press; 1997.

13. Badan Perencana Pembangunan Nasional. Pendidikan dasar 9 tahun. [online]. 2010 [cited 2012 Jul 15]. Available from: http://www.bappenas.go.id/get-file-server/node/585/
14. Badan Pusat Statistik Kota Bandar Lampung. Kota Bandar Lampung dalam angka: Bandar Lampung City in figures 2012. Bandar Lampung: Badan Pusat Statistik Bandar Lampung; 2012.

15. Harling G, Ehrlich R, Myer L. The social epidemiology of tuberculosis in South Africa: a multilevel analysis. Social Science and Medicine. 2008; 66: 492-505.

16. Ximenes RA de A, Albuquerque M de FPM de, Souza W V, Montarroyos UR, Diniz GTN, Luna CF, et al. Is it better to be rich in a poor area or poor in a rich area? a multilevel analysis of a case-control study of social determinants of tuberculosis. International Journal of Epidemiology. 2009; 38 (5): 1285-96.

17. Jackson S, Sleigh AC, Wang GJ, Liu XL. Poverty and the economic effects of TB in rural China. The International Journal of Tuberculosis and Lung Disease. 2006; 10 (10): 1104-10.

18. Atiqur R. Assessing income-wise household environmental conditions and disease profile in urban areas: study of an Indian City. GeoJournal. 2006; 65 (3): 211-27.

19. Braveman PA, Egerter SA, Mockenhaupt RE. Broadening the focus the need to address the social determinants of health. American Journal of Preventive Medicine. 2011; 40 (1S1): S4-18.

20. Kementrian Kesehatan RI. Strategi nasional pengendalian TB di Indonesia 2010-2014. Jakarta: Kementerian Kesehatan Republik Indonesia; 2011.

21. Pemerintah Republik Indonesia. Peraturan Pemerintah Republik Indonesia Nomor 17 Tahun 2010 tentang pengelolaan dan penyelenggaraan Pendidikan. Jakarta: Pemerintah Republik Indonesia; 2010.

22. Hargreaves JR, Boccia D, Evans C a, Adato M, Petticrew M, Porter JDH. The social determinants of tuberculosis: from evidence to action. American Journal of Public Health. 2011; 101 (4): 654-62.

23. WHO. Global tuberculosis report 2012. Geneva: WHO; 2012. 